\title{
Recovery of Stream Communities Following Surface Coal Mine Reclamation
}

\author{
Scott Hall ${ }^{1}$, Dave Beeson ${ }^{2} \&$ Richard Lockwood ${ }^{1}$ \\ ${ }^{1}$ ENVIRON International Corporation, Brentwood, Tennessee, USA \\ ${ }^{2} 9626$ Williams Court, Thornton, Colorado, USA \\ Correspondence: Scott Hall, ENVIRON International Corporation, 201 Summi View Drive Suite 300, Brentwood, \\ Tennessee 37027, USA. Tel: 1-615-277-7512. E-mail: shall@environcorp.com
}

\author{
Received: June 24, 2013 Accepted: July 24, 2014 Online Published: August 10, 2014 \\ doi:10.5539/enrr.v4n3p204 \\ URL: http://dx.doi.org/10.5539/enrr.v4n3p204
}

\begin{abstract}
Watershed, riparian zone, and in-stream habitat reclamation activities were implemented following surface coal mining in a headwater stream watershed. A three-year post-reclamation assessment was conducted of water quality, habitat, and biological communities. Water quality in reclaimed reaches was generally similar to that of the reference reach. Stream habitat assessments indicated "suboptimal" conditions for reference and reclaimed reaches. Fish index of biotic integrity scores indicated "fair" biotic status for reference and re-claimed reaches. Benthic macroinvertebrate riffle and multi-habitat community metrics indicated slight or no impairment in the reclaimed reaches as compared to the reference reach, and a mussel community was quickly established in reclaimed reaches despite its pre-mining absence. Overall, water quality, habitat, and biological conditions in reclaimed stream reaches were similar to those of the reference reach, demonstrating that small headwater streams can quickly recover following reclamation techniques suitable to the ecological setting. However, the recovery may have been a function of the quality of the biological communities being somewhat limited by the flat topography of the local and regional watershed.
\end{abstract}

Keywords: benthos, fish, freshwater mussels, mine reclamation

\section{Introduction}

West Fork Busseron Creek (WFBC) is a second order stream in Sullivan County, Indiana (USA). In-stream habitat is dominated by pools and runs, with infrequent riffles. Fish communities in this region are typically dominated by minnows (Cyprinidae) and sunfish (Centrarchidae) (Simon \& Dufour, 1997). Surface mining of coal initiated in 1996 resulted in relocation of approximately $2600 \mathrm{~m}$ of WFBC. A fish survey of an un-impacted WFBC reach was conducted in 2002 to determine pre-mining biological status (Three Rivers Environmental, 2003). The Rosgen stream design approach (Rosgen, 1996) was applied during stream reconstruction. The WFBC channel was reclaimed by standard construction practices that emphasized enhancing channel sinuosity and development of undercut banks. In-stream habitat improvement included addition of boulder, cobble, gravel, sand, log jams, debris dams, and root wads. Reclamation of riparian areas included planting grasses and trees compatible with regional rainfall and soil conditions. Reclamation activities were completed and flow established in reclaimed reaches in 2007.

This study was conducted in order to assess the short-term (three year) recovery of headwater stream water quality, habitat, and biological communities following stream relocation and habitat reclamation. The central hypothesis of this research was that there would be no marked differences between the biological communities of reclaimed reaches and an un-impacted WFBC reference site. Previous research has indicated that small streams can recover quickly from natural catastrophic events such as floods (e.g., Mundahl \& Hunt, 2011).

\section{Methods}

Three-year post reclamation success was evaluated in 2010 by assessing water quality and habitat quality, and the condition of the WFBC benthic macroinvertebrate and fish communities. Fish and benthic survey sites incorporated three $150 \mathrm{~m}$ study reaches. An unaltered reference site (RS) was established upstream of two reclaimed reaches ( $\mathrm{RC} 1$ and $\mathrm{RC} 2$ ). Comparable sites were chosen based on stream habitat factors. Water quality, habitat, and benthic macroinvertebrate assessments were conducted at all reaches. Fish community assessments 
were conducted in RC1 and RC2, with evaluations including comparison to 2002 baseline survey findings for comparable habitats. During the 2010 assessments, freshwater mussels were observed (but no survey was conducted), and in 2011 a Unionid mussel survey was conducted.

Water quality assessment focused on characterizing the general nature of each reach (e.g., hardness, pH), and determining the concentrations of constituents associated with surface mining impacts (e.g., cations and anions). Grab samples for chemical analyses were collected prior to other field activities, and in situ water quality analyses were conducted using a calibrated multi-parameter probe. Fish collections were conducted prior to macroinvertebrate collections so as not to disturb fish in preferred habitats. Habitat quality assessments were conducted after all in-stream activities. The Indiana Qualitative Habitat Evaluation Index (QHEI) was determined as a composite of each study reach (IDEM, 2006). Characterization of in-stream, riparian zone, and local watershed habitat and benthic macroinvertebrate communities was conducted per USEPA (1999) low-gradient stream methods. Instantaneous discharge was determined for each reach using a top-setting rod and electronic flow meter.

Benthic macroinvertebrates were collected using a qualitative multi-habitat sampling method that targeted riffle, and vegetation/debris habitats. A three square meter riffle area was sampled along with equal areas of vegetation/debris timed to approximate the riffle sampling effort. Separate riffle and vegetation/debris samples were collected for all reaches. USEPA (1999) electroshocking methods were implemented for fish collections, consistent with those used during the pre-mining assessment. Shocking proceeded until all habitats were sampled, using a two-pass method. Data collection included species-level identification, enumeration, and length and weight determinations of representative fish (minimum of five) for each size class and species. Fish index of biotic integrity (IBI) metric values and IBI scores were based on protocols in Simon and Dufour (1997) for the Eastern Corn Belt Plain Region of Indiana. Mussels were not observed during the 2002 pre-mining fish survey but were noted during 2010 field efforts. In response, mussel surveys were conducted in July 2011. The mussel survey incorporated portions of the reclaimed RC 1 Reach assessed in the fish and benthic macroinvertebrate surveys in this study, and utilized systematic sampling from random survey plots $\left(0.25 \mathrm{M}^{2}\right.$ sampling frame) per Strayer and Smith (2003). Ten- to 12-cm stream substrate samples (29 samples in RC1) were removed and placed onto a mesh screen for processing. Substrate composition and mussel species (live or relic), number of specimens, and length $(\mathrm{mm})$ of individual mussels were documented.

\section{Results}

In situ water quality determinations (data not shown) indicated somewhat lower $\mathrm{pH}$ at the $\mathrm{RS}$ reach (7.76 s.u.) as compared to RC1 and RC2 (8.07 to 8.37 s.u.) for a.m. assessments. Higher pH values of up to 9.15 s.u. were observed for the reclaimed reaches for p.m. measurements. The highest $\mathrm{pH}$ values reflect late afternoon periods when photosynthetic activity was highest, thereby increasing $\mathrm{pH}$. Dissolved oxygen was above $7.6 \mathrm{mg} / \mathrm{L}$ at all sites, and as high as $12.2 \mathrm{mg} / \mathrm{L}$ in p.m. assessments. Maximum stream temperatures were 25.3 to $31.6{ }^{\circ} \mathrm{C}$ in all reaches. The RS conductivity values ( 685 to $690 \mathrm{umho} / \mathrm{cm}$ ) were somewhat higher than those observed in the RC reaches (470 to $513 u \mathrm{mho} / \mathrm{cm}$ ) at stream flows of 5.25 to $9.95 \mathrm{cfs}$. Very similar water quality conditions with respect to $\mathrm{pH}$ and dissolved oxygen concentrations were observed during the 2011 mussel surveys. Overall, conditions were conducive to supporting warm water aquatic life.

Water sample analyses (Table 1) indicated that the concentrations of all constituents were lower at the $\mathrm{RC} 1$ and $\mathrm{RC} 2$ sites as compared to the upstream RS site. These water quality differences are not biologically meaningful given that they are relatively small between sites, and all values are well within the physiological tolerance of aquatic organisms common to the region.

Table 1. West Fork Busseron Creek Water Chemistry Results - Fish and Benthos ${ }^{(a)}$

\begin{tabular}{cccccccccc}
\hline SampleSite & $\begin{array}{c}\text { Total } \\
\text { Hardness }\end{array}$ & $\begin{array}{c}\text { Total } \\
\text { Alkalinity }\end{array}$ & Chloride & Sulfate & TDS ${ }^{(b)}$ & Calcium & Magnesium & Potassium & Sodium \\
\hline RS & 259 & 120 & 15.5 & 217 & 435 & 57.9 & 28.2 & 3.63 & 35.0 \\
RC 1 & 186 & 97.2 & 13.0 & 147 & 312 & 41.1 & 20.4 & 3.38 & 26.1 \\
RC 2 & 180 & 96.3 & 11.9 & 136 & 288 & 40.5 & 19.3 & 3.45 & 22.6 \\
\hline
\end{tabular}

(a) All values $\mathrm{mg} / \mathrm{L}$. Total hardness and total alkalinity as $\mathrm{CaCO}_{3}$. (b) Total dissolved solids. 
Composite QHEI habitat scores for reference and reclaimed reaches ranged from 50 to 53, indicating "suboptimal" conditions at all sites (data not shown). Channel morphology and most other habitat scores indicated suitable in-stream habitat at all sites. Pool/glide quality was suitable at all sites whereas riffle/run quality was poor at all sites, typical of the low-gradient streams in the region. USEPA (1999) habitat scores ranged from 123 to 135 for all sites, also indicating "suboptimal" conditions. Similar scores for comparable components of the USEPA scoring system were observed for QHEI scores. Thus, both habitat quality scoring systems indicated similar conditions for a given habitat component and the same overall habitat condition at all sites. It should be noted that vegetative cover in reclaimed reaches was limited compared to that of the RS due to the amount of time allowed for plant growth in the reclaimed reaches. Mature trees were present in the RS riparian zone as compared to full vegetative cover but immature trees in the riparian zone of reclaimed reaches. The average QHEI score for the un-impacted reach of WFBC during 2002 was 54.7 (Three Rivers Environmental, 2003).

Table 2. West Fork Busseron Creek Fish Survey Results - Present Study

\begin{tabular}{|c|c|c|c|c|c|c|c|}
\hline \multirow[b]{2}{*}{ Common Name } & \multirow[b]{2}{*}{ Genus Species } & \multicolumn{3}{|c|}{$\mathrm{RC} 1$} & \multicolumn{3}{|c|}{ RC 2} \\
\hline & & Count & $\begin{array}{c}\text { Percent } \\
\text { Individuals }\end{array}$ & $\begin{array}{l}\text { Total Biomass } \\
(\mathrm{g})\end{array}$ & Count & $\begin{array}{c}\text { Percent } \\
\text { Individuals }\end{array}$ & $\begin{array}{c}\text { Total Biomass } \\
\text { (g) }\end{array}$ \\
\hline Blackstripe topminnow & Fundulus notatus & 3 & 1 & 2.8 & 10 & 3 & 13 \\
\hline Mosquitofish & Gambusia affinis & 24 & 5 & 9.4 & 26 & 7 & 9 \\
\hline Suckermouth minnow & Phenacobius mirabilis & 62 & 12 & 282 & 71 & 20 & 203 \\
\hline Mississippi silvery minnow & Hybognathus nuchalis & - & - & - & - & - & - \\
\hline Bluntnose minnow & Pimephales notatus & 45 & 9 & 77 & 93 & 26 & 102 \\
\hline Creek chub & Semotilus atromaculatus & 2 & 0.4 & 1.7 & 16 & 4 & 18 \\
\hline Central stoneroller & Campostoma anomalum & - & - & - & - & - & - \\
\hline Creek chubsucker & Erimyzon oblongus & - & - & - & - & - & - \\
\hline Quillback & Carpiodes cyprinus & - & - & - & 2 & 1 & 14 \\
\hline Silverjaw minnow & Notropis buccatus & - & - & - & 31 & 9 & 102 \\
\hline Ribbon shiner & Lythrurus fumerus & - & - & - & - & - & - \\
\hline Redfin shiner & Lythrurus umbratilis & - & - & - & - & - & - \\
\hline Steelcolor shiner & Cyprinella whipplei & 3 & 1 & 7.8 & - & - & - \\
\hline Johnny darter & Etheostoma nigrum & - & - & - & - & - & - \\
\hline Blackside darter & Percina maculata & - & - & - & - & - & - \\
\hline Pirate perch & Aphredoderus sayanus & - & - & - & - & - & - \\
\hline White sucker & Catostomus commersonii & i 10 & 2 & 14 & - & - & - \\
\hline Spotted sunfish & Lepomis punctatus & - & - & - & 1 & 0.3 & 23 \\
\hline Bluegill sunfish & Lepomis macrochirus & 195 & 38 & 8,882 & 19 & 5 & 506 \\
\hline Green sunfish & Lepomis cyanellus & 40 & 8 & 362 & 9 & 3 & 149 \\
\hline Longear sunfish & Lepomis megalotis & 67 & 13 & 1,681 & 37 & 10 & 859 \\
\hline Largemouth bass & Micropterus salmoides & 36 & 7 & 607 & 17 & 5 & 91 \\
\hline Yellow bullhead & Ameiurus natalis & 27 & 5 & 1,137 & 24 & 7 & 445 \\
\hline Number of fish / site & & 514 & - & - & 356 & - & - \\
\hline Number of species per site & & 12 & - & - & 13 & - & - \\
\hline $\begin{array}{c}\text { Total Biomass } \\
\text { per site }(\mathrm{g})\end{array}$ & & - & - & 13,063 & - & - & 2,534 \\
\hline IBI Score (Category) & & - & - & 44 (fair) & - & - & 40 (fair) \\
\hline
\end{tabular}


Fifteen fish species (Table 2) were identified at RC1 and RC2 (12 at RC1 and 13 at RC2). The fish community at RC1 was dominated by bluegill sunfish (Lempomis macrochirus), comprising 38 percent of the individuals collected and over half the fish biomass. Other sunfishes such as the longear sunfish (L. megalotis), green sunfish (L. cyanellus), and largemouth bass (Micropterus salmoides) were also prevalent. Combined, these sunfishes accounted for 68 percent of the individuals collected and approximately 88 percent of fish biomass at RC1. The bluntnose minnow (Pimephales notatus) and suckermouth minnow (Phenacobius mirabilis) were also common at $\mathrm{RC} 1$ (nine and 12 percent of individuals collected, respectively). The bluntnose minnow and suckermouth minnow were most prevalent at RC2 (26 percent and 20 percent, respectively, of individuals collected). The sunfishes comprised only 23 percent of individuals collected at RC2 as opposed to 68 percent at RC1. However, the suckermouth minnow and bluntnose minnow, and all sunfish were relatively common at both reclaimed reaches, as were the mosquito fish (Gambusia affinis) and yellow bullhead (Ameiurus natalis).

Table 3. West Fork Busseron Creek Fish Survey Results - 2002

\begin{tabular}{|c|c|c|c|c|c|c|c|}
\hline \multirow[b]{2}{*}{ Common Name } & \multirow[b]{2}{*}{ Genus Species } & \multicolumn{3}{|c|}{$\mathrm{RS}$} & \multicolumn{3}{|c|}{$\mathrm{RC} 1$ and $\mathrm{RC} 2$} \\
\hline & & Count & $\begin{array}{c}\text { Percent } \\
\text { Individuals }\end{array}$ & $\begin{array}{c}\text { Total Biomass } \\
\text { (g) }\end{array}$ & Count & $\begin{array}{c}\text { Percent } \\
\text { Individuals }\end{array}$ & $\begin{array}{c}\text { Total Biomass } \\
\text { (g) }\end{array}$ \\
\hline Blackstripe topminnow & Fundulus notatus & 3 & 0.3 & 2.7 & 14 & 1 & 12 \\
\hline Mosquitofish & Gambusia affinis & 7 & 1 & 2.1 & 79 & 5 & 23 \\
\hline Suckermouth minnow & Phenacobius mirabilis & - & - & - & - & - & - \\
\hline Mississippi silvery minnow & Hybognathus nuchalis & - & - & - & 3 & 0.2 & 49 \\
\hline Bluntnose minnow & Pimephales notatus & 155 & 14 & 200 & 543 & 33 & 294 \\
\hline Creek chub & Semotilus atromaculatus & 307 & 28 & 3,356 & 183 & 11 & 1,976 \\
\hline Central stoneroller & Campostoma anomalum & 77 & 7 & 376 & 29 & 2 & 135 \\
\hline Creek chubsucker & Erimyzon oblongus & 1 & - & 1.9 & - & - & - \\
\hline Quillback & Carpiodes cyprinus & - & - & - & - & - & - \\
\hline Silverjaw minnow & Notropis buccatus & 168 & 15 & 292 & 428 & 26 & 372 \\
\hline Ribbon shiner & Lythrurus fumerus & 1 & 0.1 & 0.6 & - & - & - \\
\hline Redfin shiner & Lythrurus umbratilis & 14 & 1 & 12 & 20 & 1 & 9.7 \\
\hline Steelcolor shiner & Cyprinella whipplei & - & - & - & - & - & - \\
\hline Johnny darter & Etheostoma nigrum & 63 & 6 & 59 & 107 & 6 & 93 \\
\hline Blackside darter & Percina maculata & 4 & 0.4 & 11 & - & - & - \\
\hline Pirate perch & Aphredoderus sayanus & 1 & 0.1 & 9.1 & - & - & - \\
\hline White sucker & Catostomus commersonii & 2 & 0.2 & 12 & 16 & 1 & 1,076 \\
\hline Spotted sunfish & Lepomis punctatus & - & - & - & - & - & - \\
\hline Bluegill sunfish & Lepomis macrochirus & 77 & 7 & 250 & 27 & 2 & 115 \\
\hline Green sunfish & Lepomis cyanellus & 189 & 17 & 561 & 179 & 11 & 290 \\
\hline Longear sunfish & Lepomis megalotis & 19 & 2 & 189 & 32 & 2 & 143 \\
\hline Largemouth bass & Micropterus salmoides & - & - & - & 1 & 0.1 & 2.9 \\
\hline Yellow bullhead & Ameiurus natalis & 2 & 0.2 & 19 & 1 & 0.1 & 101 \\
\hline Number of fish/site & & 1,090 & - & - & 1,662 & - & - \\
\hline Number of species per site & & 17 & - & - & 15 & - & - \\
\hline $\begin{array}{c}\text { Total Biomass } \\
\text { per site }(\mathrm{g})\end{array}$ & & - & - & 5,354 & - & - & 4,692 \\
\hline IBI Score (Category) & & - & - & 44 (fair) & - & - & 42 (fair) \\
\hline
\end{tabular}


The largemouth bass was the only top carnivore collected at both reclaimed reaches, comprising five or seven percent of the fish community in each reach. Overall, the fish communities at both reclaimed reaches were similar in terms of species composition, although the dominant species at RC 1 was a centrarchid (Lepomis macrochirus) whereas a cyprinid (Pimephales notatus) was the dominant species at RC2.

Fish survey results for the reclaimed reaches (prior to stream relocation) and the RS in the 2002 baseline assessment (Three Rivers Environmental, 2003) indicated 19 species were present (Table 3) as compared to 15 species in the present study. The silverjaw minnow and bluntnose minnow were the dominant species in 2002, comprising 26 percent and 33 percent, respectively, of the individuals collected. This is in contrast to the dominance of bluegill sunfish at RC1 post-reclamation, but in general agreement with the prevalence of the bluntnose minnow observed at RC2 post-reclamation. Species present in 2002 and not observed in the present study were primarily stonerollers, darters, and shiners, including Campostoma anomalum, Lythrurus umbratilis, and Etheostoma nigrum. Four fish species were present in the reclaimed reaches in the present study but not observed in 2002; the most prevalent of these being the suckermouth minnow. Only one largemouth bass was observed in these reaches in 2002 whereas they were common at both sites in the present study. In 2002, the creek chub was the most significant contributor to fish biomass in the reaches assessed in this study as compared to the majority of biomass comprised by bluegill sunfish in RC 1 in the present study. Despite some differences between fish communities in the reclaimed reaches as compared to those observed pre-mining, the IBI scores ranged from 40 to 44 for all sites in both studies, indicating "fair" conditions (Simon \& Dufour, 1997) at all sites across time. The nearly identical IBI scores for all sites indicate similar fish community quality and recovery of the reclaimed stream reaches.

Benthic macroinvertebrate taxa richness for riffle collections at RC1 and RC2 was the same as or greater than that of the RS (Table 4).

Table 4. West Fork Busseron Creek Macroinvertebrate Survey Metric Summary for Riffle Samples

\begin{tabular}{lcccccccc}
\hline Benthic Macroinvertebrate & \multicolumn{3}{c}{ RS } & & RC 1 & & \multicolumn{2}{c}{ RC 2 } \\
\cline { 2 - 8 } Bioassesment Metric & Metric & Metric & Metric & $\%$ of & Metric & Metric & $\%$ of & Metric \\
(USEPA 1989) & Value & Score & Value & Reference & Score & Value & Reference & Score \\
\hline Taxa Richness & 23 & 6 & 23 & 100 & 6 & 38 & $>100$ & 6 \\
Hilsenhoff Biotic Index (modified) & 5.67 & 6 & 6.65 & 84.8 & 4 & 7.18 & 79 & 4 \\
Scrapers:Filter-Collectors Ratio & 0.032 & 6 & 0.01 & 31 & 2 & 0.73 & $>100$ & 6 \\
EPT:Chironomid abundance Ratio & 2.22 & 6 & 0.061 & 2.7 & 0 & 0.79 & 35.4 & 2 \\
Percent of Dominant Taxon & 47.5 & 2 & 34.1 & NA & 2 & 14.5 & NA & 6 \\
EPT Richness & 2 & 2 & 3 & $>100$ & 6 & 6 & $>100$ & 6 \\
Community Loss Index & 0 & 6 & 0.69 & NA & 4 & 0.37 & NA & 6 \\
Shredder:Total Organism Ratio & 7.7 & 6 & 12.3 & $>100$ & 6 & 20.9 & $>100$ & 6 \\
& & & & & - & - & 4.04 & -
\end{tabular}

Typical of low-gradient streams, ephemeroptera (mayfly), plecoptera (stonefly), and trichoptera (caddisfly) or EPT richness was low at all sites (two to six taxa), but the same or higher at reclaimed reaches as compared to the reference site (EPT taxa are generally sensitive to degraded water quality and degraded habitat). The shredder to total organism ratio was elevated for reclaimed reaches relative to the RS, suggesting an influx of detritus from the reclamation efforts. The percent dominant taxon value for the RS collections ( 47.5 percent) was higher than that observed for the reclaimed reach collections (14.5 to 34.1 percent), indicating a somewhat less diverse benthic community in the reference site riffle community. This was reflected by the lower Shannon diversity index value in the RS as compared to reclaimed reaches. Total Metric Scores indicated slight or no impairment in the reclaimed 
reaches as compared to the reference reach. Diptera (flies and midges), especially the chironomids, dominated the benthic community at all sites. The low gradient and generally sandy, small particle substrate of WFBC generally favors an assemblage of the taxa observed.

Table 5 presents the results of benthic macroinvertebrate vegetation/debris sampling. Taxa richness was higher in the RS collections ( 35 taxa) as compared to reclaimed reaches (22 and 28 taxa), and the percent dominant taxon value in RS collections was lower (19.3 percent) than for the reclaimed reaches (29.3 to 37.5 percent).

Table 5. West Fork Busseron Creek Macroinvertebrate Survey Metric Summary for Vegetation/Debris Samples

\begin{tabular}{|c|c|c|c|c|c|c|c|c|}
\hline \multirow{2}{*}{$\begin{array}{l}\text { Benthic Macroinvertebrate } \\
\text { Bioassesment Metric } \\
\text { (USEPA 1989) }\end{array}$} & \multicolumn{2}{|c|}{$\mathrm{RS}$} & \multicolumn{3}{|c|}{$\mathrm{RC} 1$} & \multicolumn{3}{|c|}{$\mathrm{RC} 2$} \\
\hline & $\begin{array}{l}\text { Metric } \\
\text { Value }\end{array}$ & Score & $\begin{array}{l}\text { Metric } \\
\text { Value }\end{array}$ & $\begin{array}{c}\% \text { of } \\
\text { Reference }\end{array}$ & $\begin{array}{l}\text { Metric } \\
\text { Score }\end{array}$ & $\begin{array}{l}\text { Metric } \\
\text { Value }\end{array}$ & $\begin{array}{c}\% \text { of } \\
\text { Reference }\end{array}$ & $\begin{array}{l}\text { Metric } \\
\text { Score }\end{array}$ \\
\hline Taxa Richness & 35 & 6 & 28 & 80 & 6 & 22 & 62.8 & 4 \\
\hline $\begin{array}{l}\text { Hilsenhoff Biotic Index } \\
\text { (modified) }\end{array}$ & 6.57 & 6 & 7.63 & 86.1 & 4 & 6.07 & $>100$ & 6 \\
\hline Scrapers:Filter-Collectors Ratio & 1.53 & 6 & 0.21 & 13.7 & 2 & 0.16 & 1.06 & 0 \\
\hline $\begin{array}{l}\text { EPT:Chironomid abundance } \\
\text { Ratio }\end{array}$ & 0.51 & 6 & 0.13 & 24.6 & 0 & 1 & $>100$ & 6 \\
\hline Percent of Dominant Taxon & 19.3 & 6 & 29.3 & NA & 2 & 37.5 & NA & 2 \\
\hline EPT Richness & 3 & 2 & 4 & $>100$ & 6 & 4 & $>100$ & 6 \\
\hline Community Loss Index & 0 & 6 & 0.89 & NA & 4 & 1.22 & NA & 4 \\
\hline Shredder:Total Organism Ratio & 7.1 & 6 & 13.4 & $>100$ & 6 & 16.7 & $>100$ & 6 \\
\hline Shannon Diversity & 4.13 & - & 3.64 & - & - & 3.26 & - & - \\
\hline Total Metric Score & - & 44 & - & - & 32 & - & - & 34 \\
\hline Percent of Reference Score & - & - & - & - & 73 & - & - & 77 \\
\hline Biological Condition Category & & & slight in & airment fron & eference & slight it & airment fros & eference \\
\hline
\end{tabular}

These conditions were reflected by the higher Shannon diversity index value for RS collections as compared to reclaimed reach samples. As observed for riffle collections, the shredder:total organism ratio values were higher for $\mathrm{RC}$ vegetation/debris collections as compared to $\mathrm{RS}$ collections. This reflects the higher amounts of detritus in the RC reach as opposed t the less developed RS reaches. Total Metric Scores for multi-habitat benthic macroinvertebrate collections indicated slight impairment of the benthic community in the RC reaches as compared to the RS site. The rate of benthic community development implied by the reclaimed reach benthic data is consistent with generally accepted expectations of community recovery within three to five years following episodic events, such as dam failures, floods, and reclamation (e.g., Mundahl \& Hunt, 2011).

Mussel surveys indicated two species, Utterbackia imbecillis (Paper Pondmussel) and Ligumia subrostrata (Pondmussel), were present in the RC1 reach. Eight live and two recently dead or relic U. imbecillis were found along with 15 live and one relic L. subrostarata. Calculated mussel densities based on this sampling are $1.3 U$. imbecillis $/ \mathrm{M}^{2}$ and 2.1 L subrostrata $/ \mathrm{M}^{2}$. No relationship between substrate characteristics and mussel species encountered was evident. Based on the relatively complex life cycle of freshwater mussels (e.g., need for a fish host), their presence in $\mathrm{RC} 1$ indicates that biological function of the stream has improved relative to pre-reclamation conditions when mussels were absent..

\section{Discussion}

Water quality at the RS and RC reaches was very similar with respect to $\mathrm{pH}$ and dissolved oxygen, but conductivity and individual ion concentrations were somewhat higher in the RS as compared to RC reaches. This likely indicates that water quality conditions at reclaimed reaches are primarily a function of bedrock material leaching whereas the RS water chemistry is influenced to a greater extent by leaching of materials from the more developed soils. These water quality differences were not biologically meaningful as indicated by generally 
similar benthic macroinvertebrate and fish communities. As detritus accumulates and soil depth increases in the reclaimed reaches' riparian zones, the associated leaching of materials should increase ion concentrations and conductivity to better reflect that of the reference section. Overall habitat quality scores post-reclamation were similar to those noted for WFBC prior to stream relocation, indicating recovery to conditions similar to those pre-mining. Such a recovery may relate to the fact that habitat quality in the region is typically rated as "suboptimal" due to the flat topography of the region and the WFBC watershed. Nonetheless, habitat quality in the RC reaches had recovered to conditions very similar to those observed in the RS. Following additional hydraulic and vegetative development and stabilization, the RC reaches' habitat quality may continue to improve.

Some differences were observed between fish communities pre- and post-mining. A minnow-dominated community was present pre-mining as opposed to more mixed sunfish and minnow community post-mining. Largemouth bass were present in the reclaimed reaches but rare in the pre-mining assessment. Fish community IBI scores indicated "fair" conditions in RS and both RC reaches, and taxa richness was similar for pre- and post-mining fish collections. Some differences were noted in the reclaimed reach fish communities, indicating they may not yet have reached full stability. The most notable difference was that the $\mathrm{RC} 1$ fish community was dominated by sunfish as opposed to a prevalence of minnows in the RC2 reach. However, sunfish, minnows, mosquito fish, and bullheads were common to both reclaimed reaches, and the largemouth bass was the top predator in both reaches. Some fish known to be present prior to stream relocation were absent post-reclamation, whereas some fish absent prior to stream relocation were present in post-reclamation assessments. Likewise, some differences were observed for individual benthic macroinvertebrate metrics for riffle and multi-habitat collections in the RS and RC reaches. Total Metric Scores indicated one RC reach exhibited a higher score than the RS for riffle samples, and vegetation/debris samples indicated slight impairment in RC reaches as compared to RS conditions.

Given the similar numbers of fish taxa and similar IBI scores for RC and RS reaches, and similar to slightly-impaired benthic macroinvertebrate communities in RC reaches as compared to the RS reach, the WFBC biological communities are generally similar to those of pre-mining conditions. The presence of mussels post-reclamation as compared to their absence in pre-mining assessments also indicates that the recovery of WFBC biological communities is well underway. For example, both species of Unionid mussels observed in WFBC reclaimed reaches require a fish host to complete their life cycles. The results of this study indicated that although attainable site quality is limited due to the natural setting, appreciable recovery of the relocated stream reach to the same "sub-optimal" conditions of the Reference Section was achieved within three years of completion of reclamation efforts. Continued biological recovery is expected as stabilization and maturity of the stream channel and riparian corridor proceeds towards optimal conditions.

\section{Conclusions/Recommendations}

West Fork Busseron Creek water quality and habitat had recovered to provide conditions supportive of biological communities similar to those present prior to stream relocation. The relatively rapid recovery may relate to the in-stream habitat being naturally constrained by the region's flat topography. A minnow-dominated fish community existed prior to stream relocation whereas the reclaimed reaches were dominated by minnows or sunfishes post-reclamation. The presence and absence of some species in reclaimed reaches as compared to pre-mining conditions likely indicates that the reclaimed reaches' fish communities have not yet fully stabilized. As the riparian zone plant community continues to develop, more complex in-stream habitat should also develop and result in a more diverse benthic community, particularly with regards to organisms that colonize vegetation/debris habitats like those assessed in this study. It is recommended that future studies include replication within reference and reclaimed reaches, and/or include multiple-year sampling events in order to determine the variability associated with the parameters assessed, and document when full stabilization of the biological communities has occurred. Future studies should also include assessment of the mussel community to document the extent to which mussels continue to colonize the reclaimed stream reaches.

\section{References}

IDEM. (2006). Qualitative habitat evaluation index (QHEI) - Standard Operating Procedure. IDEM Office of Water Quality Assessment Branch. Biological Studies Section.

Mundahl, N. D., \& Hunt, A. M. (2011). Recovery of stream invertebrates after catastrophic flooding in southeastern Minnesota, USA. J Freshwater Ecology. http://dx.doi.org/10.1080/02705060.2011.596657

Rosgen, D. (1996). Applied River Morphology. Wildlife Hydrology, Pagosa Springs, CO.

Simon, T. P., \& Dufour, R. (1997). Development of index of biotic integrity for the ecoregions of Indiana eastern corn belt plain. USEPA Region V, Water Division, Watershed and Non-Point Source Branch. Chicago, IL. 
Strayer, D. L., \& Smith, D. R. (2003). A guide to sampling freshwater mussel populations. Amer. Fisheries Soc. Monograph 8. Amer Fisheries Soc, Bethesda, MD.

Three Rivers Environmental. (2003). Biological inventory and substrate classification in West Fork Busseron Creek, Sullivan County Indiana. Three Rivers Environmental Assessments. Murphysboro, IL.

USEPA. (1999). Rapid bioassessment protocols for use in streams and rivers - periphyton, benthic macroinvertebrates, and Fish (2nd ed.). USEPA Office of Water Washington, DC.

\section{Copyrights}

Copyright for this article is retained by the author(s), with first publication rights granted to the journal.

This is an open-access article distributed under the terms and conditions of the Creative Commons Attribution license (http://creativecommons.org/licenses/by/3.0/). 